\title{
KANON 40 (CONTINGIT INTERDUM) IV SOBORU LATERAŃSKIEGO (1215) A PRAWO RZYMSKIE
}

\begin{abstract}
Streszczenie. W artykule zostały przedstawione cechy wspólne postępowania zaocznego w prawie rzymskim (w szczególności w epoce prawa justyniańskiego) oraz prawie kanonicznym epoki średniowiecza. Punktem wyjścia dla prowadzenia rozważań był kan. 40 IV Soboru Laterańskiego (1215 r.). Przeprowadzona analiza wykazała, iż recepcja rzymskich rozwiązań przez kościelny porządek prawny nie była jedynie działaniem mechanicznym, lecz sytuowana była także w perspektywie dostosowania starożytnych mechanizmów prawnych do wymogów doktryny chrześcijańskiej.
\end{abstract}

Słowa kluczowe: prawo kanoniczne, prawo rzymskie, IV Sobór Laterański, postępowanie sądowe, niestawiennictwo.

\section{WPROWADZENIE}

Prawo rzymskie stanowiło istotny czynnik wpływający na kształt rozwoju prawa średniowiecznej Europy. Odcisnęło ono również swój ślad na porządku prawnym Kościoła, co znalazło wyraz w często przywoływanej maksymie Ecclesia vivit lege Romana. Warto pamiętać i o tym, iż związki prawa starożytnych Rzymian oraz prawa kościelnego nie były kształtowane przypadkowo, lecz kryła się za nimi często celowa polityka prawodawcza papiestwa. Wykorzystanie rzymskich rozwiązań prawnych i ich przetransponowanie na grunt kościelny odbywało się dzięki działalności licznego grona prawników, którzy posiadali odpowiednie przygotowanie zarówno z dziedziny prawa cywilnego (inaczej rzymskiego), jak i prawa kanonicznego.

Proces oddziaływania jednego porządku prawnego na drugi mógł być ujmowany w różnoraki sposób. Prawo rzymskie było na przykład powoływane przez kościelnych prawników w charakterze autorytetu, który uzasadniał i utwierdzał ich tok rozumowania (Korporowicz 2016).

W niniejszym artykule analizie poddany zostanie kan. 40 - Contingit interdum - stanowiący owoc prac ojców soborowych IV Soboru Laterańskiego, który zebrał się w Rzymie w listopadzie 1215 r.

${ }^{*}$ Uniwersytet Łódzki, Wydział Prawa i Administracji, Katedra Prawa Rzymskiego, lkorporowicz@wpia.uni.lodz.pl 


\section{KANON 40}

Kanon 40 jest drugim z trzech prywatnoprawnych rozstrzygnięć, jakie zostały umieszczone przez ojców pośród innych soborowych postanowień. Cechą wspólną wszystkich jest ich związek z posiadaniem rozumianym jako sprawowanie władztwa faktycznego nad rzeczą, a jednocześnie osadzenie omawianych zagadnień w perspektywie procesowej. Kanon 40 dotyczy problemu nabycia posiadania rzeczy spornej przysądzonej powodowi w postępowaniu zaocznym. Kanon ten brzmi w następujący sposób:

Contingit interdum quod, cum actori ob contumaciam partis adversae adiudicatur causa rei servandae possessio, propter rei potentiam sive dolum actor infra annum rem custodiendam nancisci non potest vel nactam amittit, et sic cum secundum assertionem multorum verus non efficeretur post lapsum anni possessor, reportat commodum de malitia sua reus. Ne igitur contumax melioris quam obediens conditionis exsistat, de canonica aequitate sancimus, ut in casu praemisso actor verus constituatur elapso anno possessor. Ad haec generaliter prohibemus, ne super rebus spiritualibus compromittatur in laicum, quia non decet ut laicus in talibus arbitretur ${ }^{2}$.

Powyższe rozstrzygnięcie soborowe odnosi się do znanej prawu kanonicznemu konstrukcji zawinionego niestawiennictwa jednej ze stron na wezwanie trybunału. Nazywane było ono contumacia i występowało jeszcze w Kodeksie prawa kanonicznego z 1917 r. (kan. 1842-1851). W treści kanonu Contingit interdum dostrzec można kilka elementów, które zostały ukształtowane przez średniowiecznych kanonistów pod wpływem prawa rzymskiego. Należą do nich: po pierwsze, sama koncepcja niestawiennictwa oraz, po drugie, wprowadzenie w posiadanie rzeczy spornej. Stąd uzasadnione wydaje się rozpoczęcie dalszych rozważań od omówienia problemu zaoczności w prawie starożytnych Rzymian.

\section{ZAOCZNOŚĆ POSTĘPOWANIA W PRAWIE RZYMSKIM}

W rozwoju rzymskiego postępowania prywatnego można wskazać trzy etapy: postępowanie legisakcyjne, postępowanie formułkowe oraz postępowanie kognicyjne. Dwa pierwsze rodzaje postępowań w zasadzie nie znały problemu zaoczności w ścisłym tego słowa znaczeniu. W ustawie XII tablic wskazywano wprawdzie,

${ }^{1}$ X. II, 14, 9 i X. I, 43, 8.

${ }^{2}$ „Zdarza się, że niestawianie się strony przeciwnej powoduje przysądzenie powodowi posiadania rzeczy w celu jej strzeżenia. Jednak wskutek użycia władzy albo oszustwa powód w przeciągu roku nie może uzyskać strzeżonej rzeczy albo uzyskaną traci. W ten sposób winny czerpie korzyści ze swego przestępstwa, ponieważ wielu uważa, że po upływie roku powód nie staje się prawnym właścicielem. Aby nieposłuszny nie był w lepszej sytuacji od człowieka posłusznego, na mocy kanonicznej słuszności ustanawiamy, że w powyższym przypadku powód po upływie roku staje się rzeczywistym właścicielem. Ponadto ogólnie zabraniamy, aby w sprawach duchownych powierzano decyzję człowiekowi świeckiemu, ponieważ nie godzi się, aby świecki rozsądzał tego typu sprawy” (Baron, Pietras 2003, 279). 
iż brak stawiennictwa jednej ze stron w dniu wyznaczonym dla prowadzenia fazy apud iudicem (postępowania dowodowego) oznaczał wydanie wyroku korzystnego dla strony przeciwnej (Lex XII tab. 1, 8), jednak była to konsekwencja braku możliwości prowadzenia sporu, a nie prowadzenia postępowania pod nieobecność (Amielańczyk 2010, 12-13; 2015, 39-40). W postępowaniu formułkowym zaoczność co do zasady również była niedopuszczalna, chociaż - jak wskazuje K. Amielańczyk - istniały sposoby „zachęcenia” pozwanego do wzięcia udziału w postępowaniu. Chodzi tutaj przede wszystkim o osobę poręczyciela (vindex) oraz poręczenie majątkowe w postaci stypulacji (vadimonium). Następstwem niestawiennictwa w tych sytuacjach była missio in bona, czyli wprowadzenie powoda w posiadanie majątku pozwanego zarządzane przez pretora. Pamiętać trzeba jednak, iż wprowadzenie to dokonywało się $\mathrm{w}$ drodze ochrony pozaprocesowej mającej znamiona decyzji administracyjnej, nie było zaś ono wyrokiem zaocznym, tym samym nie była to manifestacja iurisdictio urzędnika (Amielańczyk 2010, 14). Ponadto trzeba wskazać, że przedstawione następstwa prawne dotyczyły braku pojawienia się pozwanego przed pretorem w fazie in iure. W fazie apud iudicem mógł zapaść wyrok negatywny dla nieobecnej strony, jednak nadal była to konsekwencja braku możliwości dochowania zasady kontradyktoryjności w procesie.

Ten stan rzeczy zaczął dosyć radykalnie się zmieniać, gdy rozpoczęło się kształtowanie tzw. cognitio extra ordinem. Także i w tym przypadku zjawisko zaoczności nie zostało jednak od razu w pełni przyjęte. Kształtowało się ono stopniowo, aby przybrać swoją ostateczną postać dopiero w okresie prawa justyniańskiego (Kaser 1966, 379).

W procesie kognicyjnym uwzględniono możliwość niestawienia się zarówno strony powodowej, jak i pozwanej. Przedstawione wcześniej namiastki zaoczności odnosiły się jedynie do osoby pozwanego. Była to konsekwencja wprowadzenia urzędowej formy wezwania stron do uczestnictwa w procesie. Niestawiennictwo było zatem niesubordynacją obywatelską czy inaczej nieposłuszeństwem (contumacia) i stąd wymagało stosownego napiętnowania (Szymoszek 1980, 7-8; Amielańczyk 2010, 16). Drugą ważną zmianą było dopuszczenie prowadzenia postępowania dowodowego i wydanie wyroku na jego podstawie.

W prawie justyniańskim (po 542 r.) w przypadku pozwanego sędzia był zobowiązany ogłosić edykt wzywający go do stawiennictwa. Należało ponowić go trzykrotnie, jeśli okazywał się nieskuteczny. Jeśli wszystkie wezwania zostały zignorowane przez pozwanego, sędzia wydawał tzw. edictum peremptorium, w którym ogłaszał jego nieobecność i obwieszczał możliwość wydania wyroku zaocznego na korzyść powoda, co w praktyce zazwyczaj miało miejsce. Konsekwencją wydania wyroku zaocznego była utrata przez pozwanego niemal wszystkich środków odwoławczych, jakie przysługiwałyby mu, gdyby uczestniczył w procesie ${ }^{3}$.

\footnotetext{
${ }^{3}$ Kazuistycznie opracowany materiał dotyczący tej kwestii umieszczony został przez kodyfikatorów justyniańskich w tytule Quomodo et quando iudex sententiam proferre debet praesentibus partibus vel una absente Kodeksu Justyniana (C. 7, 43).
} 
Nowele justyniańskie zawierają również rozstrzygnięcia dotyczące nieobecności powoda (Nov. 112, 3). Problem ten był wprawdzie zauważany wcześniej, jednak nie stanowił on przedmiotu większego zainteresowania prawników i ustawodawcy ${ }^{4}$. Justynian postanowił zastosować wobec nieobecnego powoda te same środki, co w przypadku pozwanego. Udzielił on pozwanemu prawa żądania od sędziego wydania edyktu wzywającego powoda do stawienia się w sądzie. Edykt taki mógł być ponawiany trzykrotnie co 30 dni. Po ogłoszeniu nieobecności powód mógł przystąpić do procedowania w ciągu następnego roku, jeśli zaś nie skorzystał z tej możliwości, sędzia miał możliwość wydania wyroku zaocznego. Co ciekawe, jeśli przystąpił jednak do prowadzenia postępowania, wówczas sędzia miał możliwość nakazaniu mu pokrycia kosztów procesowych poniesionych przez pozwanego, wynikających z opóźnienia w procedowaniu (Nov. 112, 3, 2; zob. szczegółowo: Szymoszek 1980, 8-10).

Jedną z możliwych konsekwencji niestawiennictwa stron w procesie rzymskim było wprowadzenie strony przeciwnej w posiadanie majątku przeciwnika procesowego. Jak zostało już wspomniane, taka możliwość występowała już $\mathrm{W}$ epoce postępowania formułkowego. $\mathrm{W}$ tym przypadku jednak missio in bona zastępowała wyrok oraz ogłaszana była przez pretora jako następstwo niestawiennictwa przed nim. W kontekście analizowanego kanonu Contingit interdum bardziej uzasadnione wydaje się przyjrzenie się konstytucji cesarskiej z roku 290, wydanej przez Dioklecjana i Maximianusa, która brzmi:

[...] a quo ter citatus si contumaciter praesentiam sui facere neglexerit, non abs re erit vel ad cogendum eum, ut se repraesentaret, possessionem bonorum cui incumbit ad te transferre et adversarium petitorem constituere, vel auditis defensionibus tuis id quod iuris ratio exegerit iudicare ${ }^{5}$.

Reskrypt cesarski dotyczy procedowania według cognitio extra ordinem, na co wskazuje trzykrotne wezwanie nieposłusznego przeciwnika procesowego. Imperatorzy obwieścili, iż w razie niestawiennictwa sędzia może wybrać jedno z trzech zaproponowanych rozwiązań: może zmusić nieobecnego do wzięcia udziału w procesie, może wprowadzić obecną stronę w posiadanie majątku przeciwnika albo może wysłuchać argumentów ${ }^{6}$ strony obecnej i wydać wyrok.

Opisane uprawnienie sędziego do wprowadzenia strony przeciwnej w posiadanie majątku przeciwnika procesowego stanowiło przedmiot dalszej ewolucji. $\mathrm{W}$ epoce prawa justyniańskiego stanowiło ono już - jak pokazuje E. Szymoszek - zasadniczy sposób działania w razie niestawiennictwa pozwanego, jeśli doszło do niego jeszcze przed litis contestatio. Zdaniem E. Szymoszka w przypadku

${ }^{4} \mathrm{O}$ istnieniu problemu świadczyć może passus autorstwa Ulpiana zamieszczony przez kodyfikatorów justyniańskich w D. 42, 2, 6, 3 (Ulpianus libro quinto de omnibus tribunalibus).

${ }^{5}$ C. $7,43,8$.

${ }^{6} \mathrm{~W}$ reskrypcie wskazuje się na auditis defensionibus tuis, co oznacza, iż pytanie skierowane zostało do cesarzy przez uczestniczącego w procesie pozwanego pod nieobecność powoda. 
skarg in rem powód miał prawo żądać wydania mu rzeczy, zaś w przypadku skarg in personam miał być on wprowadzony w posiadanie majątku w celu zaspokojenia wierzytelności. Niezależnie jednak od oczywistych różnic, które stanowiły następstwo typologii skarg w prawie rzymskim, godny uwagi wydaje się fakt, iż w obu przypadkach rozwiązaniem miało być takie czy inne wydanie rzeczy powodowi (Szymoszek 1980, 9).

\section{ZAOCZNOŚĆ POSTĘPOWANIA W PRAWIE KANONICZNYM EPOKI KLASYCZNEJ}

W prawie kanonicznym, tak samo jak w prawie rzymskim, contumacia była nieusprawiedliwionym niestawiennictwem na wcześniejsze wezwanie sędziego. Zgodnie z rozwiniętym średniowiecznym ordo iudiciarius strona, która nie stawiła się w sądzie po trzech wezwaniach, uznawana była za nieobecną, zaś postępowanie mogło toczyć się zaocznie. Zazwyczaj nieobecnym był pozwany, co oznaczało, iż w większości przypadków już na wstępie postępowania oczywiste było, iż zapadnie wyrok korzystny dla powoda. Wyrok taki nie kończył jednak postępowania. Pozwanemu dawano bowiem roczny termin na ustosunkowanie się do zapadłego wyroku, który uprawomocniał się z jego upływem. Wówczas pozwany mógł zostać ekskomunikowany (por. Helmholz 2004, 163-164; Brundage 2013, 129-130). Przedstawione rozwiązanie stanowiło schemat ogólny, do którego prawnicy średniowieczni dążyli stopniowo (więcej zob. Litewski 1999, 285-291).

Już w Decretum Gracjana odnaleźć można stosunkowo dużą grupę źródeł, która dotyczy problemu niestawiennictwa stron. Ojciec prawa kanonicznego nie postrzegał ich jednak jeszcze jako pewnego oddzielnego zespołu regulacji. Contumacia u Gracjana pojawia się zatem w różnych częściach jego zbioru, często stanowiąc jednocześnie zaledwie jedną $\mathrm{z}$ kilku rozstrzyganych $\mathrm{w}$ danym przypadku wątpliwości. Warto ponadto zauważyć, iż w Decretum termin contumacia używany jest również wielokrotnie w swoim codziennym, a nie technicznym znaczeniu. Stąd na przykład odnaleźć można informację o nieposłusznych duchownych $^{7}$ czy o nieposłuszeństwie względem Stolicy Apostolskiej ${ }^{8}$. Regulacje takie nie mają wówczas nic wspólnego z przedmiotowym zagadnieniem niestawiennictwa w sądzie. Pokazują one jednocześnie, iż zbiór Gracjana stanowił kompilację różnorodnych źródeł, w których nie zawsze posługiwano się usystematyzowaną siatką pojęć.

Inaczej problem ten przedstawia się jednak w Liber Extra Grzegorza IX. Święty Rajmund z Penyafort, odpowiedzialny za przygotowanie papieskiego zbioru, zebrał przypadki dotyczące niestawiennictwa stron w tytule De dolo et

\footnotetext{
${ }^{7}$ D. 32 , c. 9 ; D. 50 , c. 21.

${ }^{8}$ D. 17 , c. 4.
} 
contumacia ${ }^{9}$. Warto zwrócić na ten fakt uwagę, gdyż wskazuje, że niestawiennictwo, stanowiące przedmiot dalszych rozważań, musiało mieć charakter celowy czy wręcz zawiniony. We wskazanym tytule zebrane zostały papieskie dekretały wydane przez Aleksandra III (1159-1181), Urbana III (1185-1187), Innocentego III (1198-1216) oraz Grzegorza IX (1227-1241). W następnym tytule, De eo, qui mittitur in possessionem causa rei servandae ${ }^{10}$, który dotyczy przeniesienia posiadania przedmiotu sporu na powoda w przypadku nieobecności strony pozwanej, powtórzony został schemat znany już uprzednio. Zebrano w nim dekretały Aleksandra III, Klemensa III (1187-1191), Innocentego III oraz Grzegorza IX. Analiza powyższych dekretałów pozwala spostrzec, iż kanoniczna contumacia nie zaczęła rozwijać się jako samodzielna instytucja prawa wcześniej niż w połowie XII w.

Niezależnie jednak od późnego pojawienia się kanonicznej wersji zaoczności postępowania, w tych rozwiązaniach można wyraźnie dostrzec rzymskie reminiscencje. Widać to przede wszystkim w obowiązku potrójnego wezwania nieobecnej strony do wzięcia udziału w postępowaniu. Po drugie, uwagę zwraca roczny termin wstrzymujący wykonalność wyroku. W tym przypadku widać nieco zmodyfikowane rozwiązanie znane prawu justyniańskiemu, dotyczące rocznego terminu umożliwiającego pozwanemu przystąpienie do postępowania. Wreszcie, po trzecie, konsekwencją niestawiennictwa było w prawie kanonicznym missio in possessionem.

\section{AEQUITAS RZYMSKA A AEQUITAS CANONICA}

Analizowany kanon Contingit interdum może być interesujący z jeszcze jednego powodu, jakim jest krótka fraza pojawiająca się pod jego koniec. Ojcowie soborowi wskazali, iż ut in casu praemisso actor verus constituatur elapso anno possessor. Dodali również, że uzasadnieniem tego postanowienia jest słuszność kanoniczna (aequitas canonica). Użyte sformułowanie wydaje się początkowo niezgodne z przedstawionymi powyżej ustaleniami. Roczny termin - jak wykazano - pojawiał się już w prawie justyniańskim. Słuszność kanoniczna, o której jest jednak mowa, nie została przywołana przez autorów kanonu w kontekście rocznego terminu, lecz raczej w odniesieniu do siły (potentia) oraz podstępu (dolus), z jakimi działał contumax, aby uniemożliwić nabycie posiadania spornego przedmiotu przez powoda przed upływem jednego roku.

Aequitas canonica jest pojęciem, które tylko w pewnym stopniu można wiązać z rzymską koncepcją aequitas. Jej dzieje nie mogą być datowane wcześniej niż połowa XII w., gdy została ona opisana jako jedna z metod interpretacji prawa przez autora pochodzącego ze szkoły prawa Martianusa, działającego w południowej Francji. Co ciekawe, szkoła Martianusa była szkołą prawa rzymskiego.

\footnotetext{
${ }^{9}$ X. 2, 14.

${ }^{10}$ X. 2, 15 .
} 
Nie przeszkadzało to jednak tworzącym ją jurystom zajmować się również prawem kanonicznym. Gracjan, sporządzający Decretum kilkadziesiąt lat późnej, nie używa jeszcze pojęcia aequitas canonica. Po raz pierwszy słuszność wykorzystana została do zdefiniowania jakości prawa kanonicznego dopiero przez Eugeniusza III w jego dekretale z roku 1150 (por. Lefebvre 1963, 122-136; Sobański 1973, 130-132; Landau 1994, 95-99; Brugnotto 1999).

Jak wskazuje P. Landau, od czasów pontyfikatu Aleksandra III można zaobserwować rosnącą liczbę odwołań do aequitas canonica. Jej zastosowanie nakierowane było w dużym stopniu na przekształcenie rzymskich rozwiązań proceduralnych. Niemiecki historyk prawa stwierdził: ,aequitas could be used as a general principal to give judges practical independence without breaking obedience to the letter of the law" (Landau 1994, 100). Ponadto aequitas stała się instrumentem zmiany prawa oraz uzupełniania luk prawnych (tamże, 101). W Contingit interdum odwołanie się do słuszności kanonicznej doskonale obrazuje sposób jej wykorzystania i zestawienia regulacji prawnej z wymogami doktryny chrześcijańskiej. W soborowym rozstrzygnięciu prawnym nie chodziło bowiem tylko o zmianę prawa procesowego, lecz także o zapobieżenie grzesznej praktyce pozwanych, którzy działali z siłą i podstępnie. Warto dodać, iż ojcowie soborowi decydując się na powyższe rozwiązanie, zaakceptowali tym samym istnienie fikcji prawnej. Verus possessio, które przyznane zostało powodowi, zostało bowiem pozbawione wymogu faktycznej detencji przedmiotu sporu. Ochrona działań i pozycji prawnej „posłusznego” powoda była jednak w oczach Kościoła ważniejsza niż ścisłe zastosowanie przesłanek rządzących nabyciem posiadania. Temu sposobowi myślenia autorów kanonu odpowiada próba zdefiniowania tego, czym jest słuszność kanoniczna przez R. Sobańskiego: ,chodzi bowiem o uwzględnienie sytuacji subiektywnej, stworzenie warunków, by prawo obiektywne istotnie osiągnęło w odniesieniu do każdego człowieka swój zbawczy sens" (Sobański 1973, 130).

\section{PODSUMOWANIE}

Contumacia, której dotyczy kan. 40 Contingit interdum IV Soboru Laterańskiego, stanowiła z pewnością jeden z ważniejszych problemów procesowych, którym zajęli się zgromadzeni w $1215 \mathrm{r}$. ojcowie soborowi. Wprawdzie w treści kanonu nie można odnaleźć bezpośrednich nawiązań do prawa rzymskiego, to jednak konstrukcja zaoczności, która przedstawiona została we wspomnianym kanonie wyraźnie nawiązuje do późnorzymskich rozwiązań procesowych. Kanon Contingit interdum jest wyrazistym obrazem relacji łączącej prawo rzymskie z prawem kanonicznym w epoce średniowiecza. Odwołanie do aequitas canonica wskazuje, iż recepcja starożytnych rozwiązań prawnych przez Kościół nie była tylko zabiegiem mechanicznym, lecz była poddawana swoistemu „retuszowi”, który stanowił następstwo odwołania się do chrześcijańskiej doktryny i celu prawa kościelnego, jakim jest zbawienie dusz. 


\title{
BIBLIOGRAFIA
}

Amielańczyk, Krzysztof. 2010. „Postępowanie zaoczne: rzymskie i współczesne dylematy władzy sądowniczej”. Studia Prawnoustrojowe 12: 9-26.

Amielańczyk, Krzysztof. 2015. „Zasada skargowości i zakaz orzekania ponad żądanie stron w procesie rzymskim". Gdańskie Studia Prawnicze 33: 33-46.

Brugnotto, Giuliano. 1999. L',Aequitas canonica”. Studio e analisi del concetto negli scritti di Enrico de Susa (Cardinal Ostiense). Roma: Editrice Pontificia Università Gregoriana.

Brundage, James A. 2013. Medieval Canon Law. Abingdon-New York: Routledge.

Baron, Aarkadiusz, Henryk Pietras. 2003. Dokumenty soborów powszechnych. Tekst grecki, taciński, polski. T. 2. Układ i oprac. A. Baron, H. Pietras. Kraków: Wydawnictwo WAM.

Helmholz, Richard H. 2004. The Canon Law and Ecclesiastical Jurisdiction from 597 to the 1640s. (The Oxford History of the Laws of England. Vol. 1. Ed. John H. Baker). Oxford: Oxford University Press.

Kaser, Max. 1966. Das Römische Zivilprozessrecht. München: C.H. Beck.

Korporowicz, Łukasz Jan. 2016. „Rzymskie inspiracje kanonu 39 (Saepe contingit) IV Soboru Laterańskiego (1215)”. Łódzkie Studia Teologiczne 25 (2): 91-102.

Landau, Peter. 1994. "Aequitas in the Corpus Iuris Canonici”. Syracuse Journal of International Law \& Commerce 20: 95-104.

Lefebvre, Charles. 1963. "Natural Equity and Canonical Equity". Natural Law Forum 1963: $122-136$.

Litewski, Wiesław. 1999. Der römisch-kanonische Zivilprozeß nach den ältern ordines iudiciarii. T. 1. Kraków: Wydawnictwo Uniwersytetu Jagiellońskiego.

Sobański, Remigiusz. 1973. Zarys teologii prawa kościelnego. Warszawa: Akademia Teologii Katolickiej.

Szymoszek, Edward. 1980. „Pozycja sędziego wobec stron w procesie justyniańskim”. Acta Universitatis Wratislaviensis 516, Prawo XCI: 3-15.

\section{Łukasz Jan Korporowicz OPS}

\section{CANON 40 (CONTINGIT INTERDUM) OF THE FOURTH LATERAN COUNCIL (1215) AND ROMAN LAW}

\begin{abstract}
The article discusses the problem of familiar features of the proceedings in default in Roman law (especially in Justinian's law) and the medieval canon law. The starting point of this analysis is can. 40 of the Fourth Lateran Council (1215). The undertaken study has shown that the reception of Roman legal solution by the legal system of the Church was not only mechanical, but it was also situated in the context of adapting ancient legal provisions to the doctrinal needs of the Christianity.
\end{abstract}

Keywords: canon law, Roman law, Fourth Lateran Council, legal procedure, absence. 